\title{
A CAFÉ CORONARY DEATH DUE TO A 'BANANA'
}

\author{
P.A.S. Edirisinghe \\ Senior Lecturer, Department of Forensic Medicine, Faculty of Medicine University of \\ Kealniya, Sri Lanka

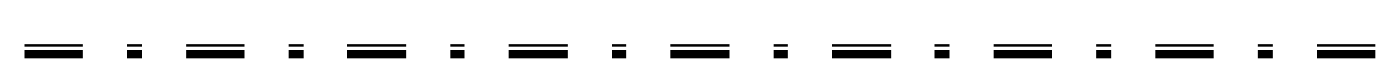

\section{Abstract}

Café Coronary syndrome which was first reported as sudden collapse at restaurants while dining was found to be due to fatal occlusion of upper airway by large pieces of food. Many of those individuals had consumed large amounts of alcohol prior to the incident. However, same condition has also been noticed among institutionalized elderly with dementia and psychiatric conditions. This is an un-witnessed death of a café coronary syndrome, where a 70 year old man after having dinner with his children previous night found dead next day morning in his bed. At autopsy a blob of mucoid secretions were found at right nostril and a piece of banana weighing $21 \mathrm{~g}$ was found impacted within the laryngophrarynx, occluding the air way. He was edentulous. This case highlights the need of being aware of the condition especially in the elderly with mastication problems due to lack of teeth and other deglutition problems.

\section{Introduction}

Café coronary syndrome introduced in 1963 by Haugen referring to obstruction of the upper airway by a bolus of food witnessed by others is not only limited to elderly but also to the very young and neurologically impaired persons in institutions. [1][2][3]. Many of these witnessed cases can be saved with proper, prompt emergency care while awareness of the condition can minimize the deaths that are not witnessed. The case on discussion highlights the need of being aware of the condition especially those elderly who lack

teeth or those who tend to gulp food without mastication.

\section{Case report}

70 year old edentulous man had dinner with his children previous night and retired to his room with a banana, given as his desert, stating that he would eat it later. Next morning he was found dead in his bed with some secretions from nose and mouth. Resuscitation was not attempted. The deceased was an active man who was engaged in farming, but occasionally complained of a chest pain aggravated with exertion. He was a non smoker and a teetotaler.

At autopsy, a blob of mucoid sections, mixed with food particles were found at right nostril, (image 1) while a large piece of banana $(7.2 \mathrm{~cm} \mathrm{x} 4 \mathrm{~cm})$ weighing $21 \mathrm{~g}$ was found firmly lodged in the laryngopharynx. (Image 2) It was moulded to the shape of the laryngeal anatomy. The broken surface was facing the epigllotis and extending up to vocal cords obstructing the lumen completely. There was a contusion measuring $1 / 2 \mathrm{~cm} \times 3 / 4 \mathrm{~cm}$ in the posterior surface of epiglottis, surrounded by congestion of the blood vessels. When the main piece of banana was dislodged from its position small pieces of banana were found in right aryepiglotic fold (Image $3 \&$ 4). The banana piece also had the indentation of the epiglottises. The trachea 
and the bronchi contained mucoid secretions mixed with food, but these were not extending to bronchioles. The stomach contained $400 \mathrm{ml}$ of partly digested food. There were 3 smaller pieces of banana in the stomach. Lungs were normal. Moderate atherosclerosis was present within major vessels but coronaries ostea were patent with minimal atherosclerosis. No other significant underlying diseases were present. Blood was not tested for alcohol as the deceased was a teetotaler.

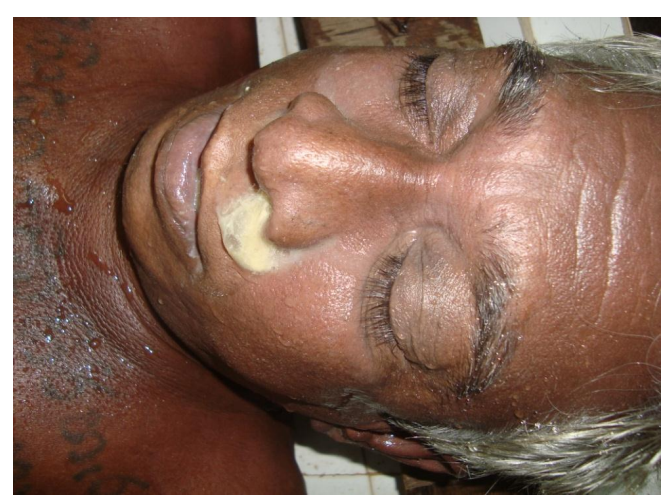

Figure - 1

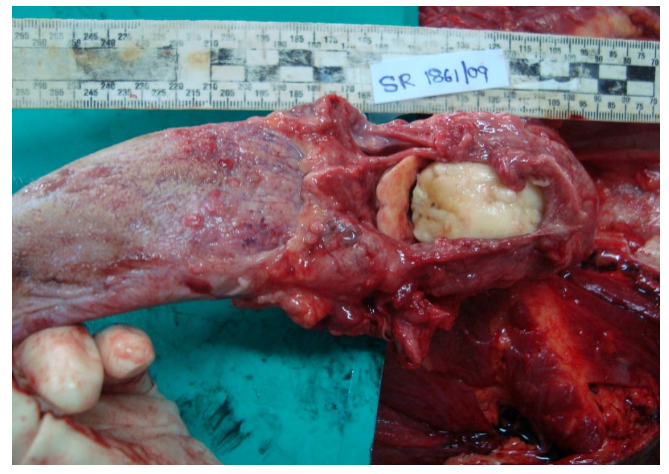

Figure - 2

\section{Discussion}

áChokingô or obstruction of upper air, i.e between pharynx and bifurcation of trachea is a well known phenomenon in forensic literature for many centuries and asphyxiation of food has been recognized as a cause of sudden accidental death. [4][5] Café coronary syndrome or death due to acute obstruction of upper air way by impacted food while eating was first described in deaths at restaurant where the

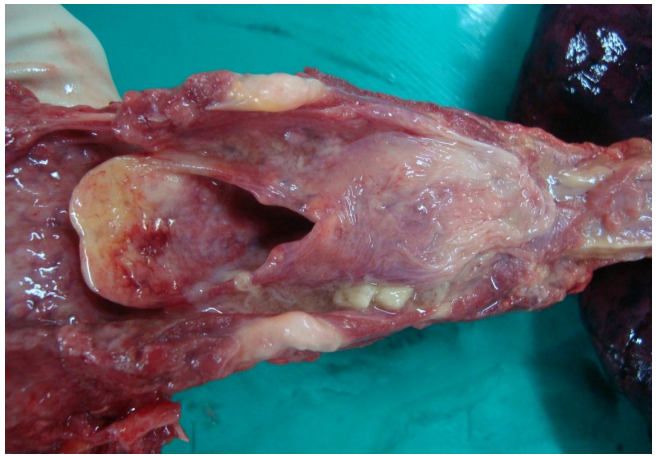

Figure -3

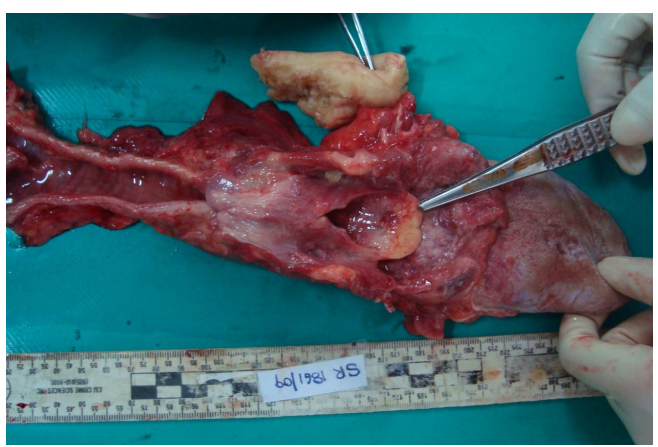

Figure - 4

victim collapsed in front of others most of the time trying to swallow a piece of meat. [1]. However, later rare variants have been reported such as coprophagic café coronary [6] and therapy related café coronary.[7]

Although, old age, inadequate mastication due to poor dentition/denture and alcohol consumption were well known predisposing factors, sedatives drugs and anti-parkinsonism drugs were also found to have an increased predisposition. [8][9]. However, reported predisposing factors for children were inadequate dentition for the food provided and lack appropriate eating skills [10],[11].

Mittlman and Wetli in their study of 141 autopsy cases state the commonest type of food involved in ớree roaming adultsò was meat while in ñnstitutionalized adultò commonest agent was soft friable snack food like bananas, bread and peanut butter. Berzlanovich et al in a 273 autopsy population also showed a similar trend where significantly higher asphyxiation of 
soft/slick foods (p <0.007) with agomphiasis (p <0.002), occurring frequently during lunch in more elderly population in contrast to choking of large pieces of foreign material $(p<0.002)$ with higher rate of blood alcohol concentration ( $\mathrm{p}<0.001)$ in younger elderly group. [12]. Children show a different trend compared to elderly where commonly asphyxiated food item being hot dogs followed by various items including candy, popcorn to toy rattle and tissue paper. [13].

One of the important issues a pathologist should be aware of diagnosis of café coronary is the exclusion of an aspiration. A simple test of litmus on the acidity will solve the issue indicating the secretions found in the lower respiratory tract were not coming from the stomach.

\section{Conclusion}

Eating smaller portions, prior munching, crumbling of the food, avoiding gulping quickly are some measures that edentulous elderly must be aware of if we are to prevent deaths from café coronary syndrome. However, if such situation occurs awareness of emergency treatment manures like Heimlich maneuver will save many of these lives. [14]

\section{References}

1. Haugen RK. The café coronary: sudden deaths in restaurants. JAMA. 1963;186:142ї 4.

2. Mittleman RE. Fatal choking in infants and children. Am J Forensic Med Pathol. 1984;5:20110.

3. Mittleman RE, Wetli CV. The fatal cafe coronary. Foreign-body airway obstruction, JAMA. 1982; 247:1285-8.

4. Suffocation and asphyxia in Knightôs Forensic Pathology eds. Pekka Saukko \& Bernard Knight Arnold, London $3^{\text {rd }}$ Ed 361-363

5. Clerf LH: Historical aspects of foreign bodies in the air and food passages. South Medical J. 1975;68:1449-1454.

6. Byard RW. Coprophagic café coronary. Am J Forensic Med Pathol. 2001;22:96ï 9.

7. Hunsaker D.M, Hunsaker J.C. Therapy-Related Café Coronary Deaths; Two Case Reports of Rare Asphyxial Deaths in Patients under Supervised Care Am J Forensic Med Pathol. 2002;.23:149 ï 154.

8. Jacob B, Wiedbrauck C, Lamprecht J, Bonte W. Laryngologic aspects of bolus asphyxiation-bolus death. Dysphagia. 1992;7:31ï 5.

9. Schmitt MF, Hewer W. Life threatening situations caused by bolus aspiration in psychiatric inpatients--clinical aspects, risk factors, prevention, therapy. Fortschr Neurol Psychiatr. 1993;61:313-8.

10. Byard RW. Unexpected death due to acute airway obstruction in daycare centers. Pediatrics. 1994;94:113ї 4.

11. Byard RW. Mechanisms of unexpected death in infants and young children following foreign body ingestion. $J$ Forensic Sci. 1996;41:438ї 41.

12. Berzlanovich AM, Fazeny-Dörner B Waldhoer T, Fasching P, Keil W Foreign body asphyxia: a preventable cause of death in the elderly. Am $J$ Prev Med. 2005;28(1):65-9.

13. Mittleman RE. Fatal choking in infants and children. Am J Forensic Med Pathol. 1984;5:201-10.

14. Heimlich HJ, Patrick EA. The Heimlich maneuver. Best technique for saving any choking victim's life. Postgrad Med. 1990 ;87:38-48, 53. 